\title{
Research on the Impact of FDI in Producer Services on Carbon Emissions
}

\author{
Danlei Yang ${ }^{1, *}$ \\ ${ }^{1}$ Beijing JiaoTong University, School of Economics and Management, 100044 Beijing, China
}

\begin{abstract}
Under the background of global warming, how to reduce carbon emissions and realize green and sustainable development in China is worth exploring. Firstly, this paper makes theoretical analysis, and considers that FDI in producer services can reduce the carbon emission of manufacturing industry by optimizing the input structure of manufacturing industry, improving the productivity and technical level, and enhancing the management ability and resource allocation ability of manufacturing enterprises. Then, using the panel data of China's industries from 2004 to 2014, this paper uses two-way FE method to carry out empirical test, and finds that the increase of FDI in producer services can significantly reduce carbon emissions. Therefore, it is necessary to actively guide multinational corporations to invest in China's producer services industry, to promote green and sustainable economic development.
\end{abstract}

\section{Introduction}

Reducing carbon dioxide emissions and slowing climate warming is a major environmental problem facing all countries in the world. With the rapid economic growth, China is facing the problem of increasing carbon emissions. In order to coordinate economic development and environmental problems, the report of the 19th National Congress of the Communist Party of China continues to emphasize the need to promote green development and establish and improve the economic system of green and low-carbon circular development. Under the background of the New Normal, the issue of how to promote the "mode transformation and structure adjustment "of China's economy and realize the green development of economy has been widely concerned.

Producer services have the characteristics of knowledge intensive, low pollution, low consumption, high output and high employment, which can optimize the industrial structure and provide an effective way to realize low-carbon economy[1].However, there are some problems in China's producer service industry, such as the development is relatively backward and the structure is unreasonable. In order to develop producer service industry, the relevant documents of the State Council put forward that 'further expand the opening-up, guide foreign-funded enterprises to set up producer service enterprises in China'. Therefore, the impact of foreign direct investment (Hereinafter referred to as FDI) on industrial carbon emissions is worth exploring.

\subsection{Related work}

The existing studies on the environmental effects of FDI mainly start from the field of manufacturing industry.
The internationally recognized viewpoints include the "pollution paradise hypothesis" proposed by Walter and Ugelow (1979) and "pollution halo hypothesis" proposed by Kevin Grey and Duncan Brank (2002), the former thinks that the transfer of heavy pollution and high energy consuming industries by transnational corporations to developing countries will bring negative impact on the ecological environment of developing countries, the latter thinks that transnational corporations can bring high standard production mode and advanced technology to the host country, thus helping to reduce the emission of local pollutants. Further studies suggest that the relationship between FDI and carbon emissions in manufacturing industry is nonlinear and will be affected by other factors, such as the level of intellectual property protection [2] and the level of human capital [3].

In terms of the impact of FDI in service industry on the environment, a study have found that FDI in service industry drives the upgrading of industrial structure through capital effect and technological effect, and both FDI in service industry and upgrading of industrial structure can restrain $\mathrm{CO} 2$ emission in China [4]. Although there are few studies on the environmental effects of FDI in the service industry, the existing literature has widely focused on the impact of service industry development on the environment, including the research on the impact of industrial structure adjustment, producer services agglomeration, and the manufacturing sertivization on the environment.

\subsection{Contributions}

There are few studies on the impact of FDI in service industry on carbon emissions. This paper innovatively focuses on producer services and explores the impact of

\footnotetext{
*Corresponding author: 18120552@bjtu.edu.cn
} 
FDI in producer services on industrial carbon emissions at the industry level. To clarify the relationship between FDI in producer services and industrial carbon emissions is of great significance to maintain high-quality economic development and strengthen the construction of ecological civilization in the new normal period.

\section{Theoretical analysis}

\subsection{Optimize the input structure}

FDI in producer services can optimize the input structure of manufacturing industry. Firstly, service factor input partially replaces energy factor input, thus reducing energy consumption in manufacturing process [5]. Producer services are used to meet the intermediate needs of the production process. The input of producer services can make manufacturing enterprises extend to high value-added links such as R\&D and after-sales in the value chain. In order to obtain more benefits, enterprises will choose to increase the input of producer services, which will reduce the input of energy elements, and reduce carbon emissions in the production process. Secondly, producer services FDI can directly provide a variety of high-quality service products, and can also reduce the price of local service products through competitive effect. Therefore, manufacturing enterprises are more willing to choose service outsourcing. Service outsourcers have higher efficiency and can achieve the same service function with lower energy consumption. Finally, because producer services are independent from the manufacturing industry and have a natural and close economic relationship with the manufacturing industry, green producer services can embed the concept of green development into the manufacturing industry, produce radiation effects, and drive the green development of manufacturing industry [6].

\subsection{Increase productivity and technical level}

FDI in producer services can improve the productivity and technical level of manufacturing industry, and the improvement of productivity and technical level is conducive to reducing carbon emissions. Producer services FDI can promote downstream manufacturing enterprises to choose service outsourcing. This specialization makes enterprises invest more capital in the R \& D of core technology, to improve the technical level of enterprises. Producer service industry runs through the whole process of production, needs the intermediate products provided by upstream manufacturing industry. In order to obtain intermediate products that meet the demand, foreign-funded enterprises in service industry will not only provide technical guidance to manufacturing enterprises directly, but also force manufacturing enterprises to improve technology and production efficiency with higher product standards. On the one hand, technological innovation controls pollution emissions from the source, on the other hand, it enriches pollution treatment methods, saves treatment costs, and provides the possibility for enterprises to prevent and control pollution from the front-end links of production [6]. The improvement of production technology often means that the same products can be obtained with less intermediate investment, and the improvement of resource utilization rate is helpful to reduce carbon emissions.

\subsection{Improve management and resource allocation capability}

FDI in producer services can improve the management level and resource allocation ability of manufacturing enterprises. High quality producer services can strengthen the internal and external connections of enterprises, and improve the overall planning ability of enterprises and optimize the allocation of resources. For example, within an enterprise, information technology services help to establish office automation systems, strengthen the links between departments, realize information resource sharing, and help management make decisions. Information technology can also help enterprises establish enterprise resource planning system, carry out supply chain management, and better optimize enterprise resources. Outside the enterprise, transportation and communication technology can help enterprises to strengthen their ties with other enterprises in the upstream and downstream of the industrial chain, to make more reasonable purchase and sales plans. Between the enterprise and the market, the business consulting service can help the enterprise to understand the market, so that the enterprise can adjust the production plan according to the market demand, and avoid excessive production and waste of resources. In addition, foreign-funded enterprises in producer services, which are relatively rich in capital and technology, often have advanced organizational management level and marketing capabilities, which not only provides learning opportunities for local service enterprises, but also breaks through the industrial boundaries to carry out technology spill-over to manufacturing enterprises, which helps local enterprises improve their operation and management level

\section{Empirical research}

\subsection{Variables}

The explained variable is carbon emission $\left(\mathrm{CO}_{2}\right)$ including the $\mathrm{CO} 2$ emissions from the combustion of 17 fossil fuels and the production process of cement industry, the calculation method is based on Cai et al. [7].

The main explanatory variable is FDI penetration rate (SFDI) of producer services. In order to distinguish the differential impact of FDI in producer services on different manufacturing industries, this paper uses the methods of Arnold [8] for reference, and constructs the index of FDI penetration rate of producer services. The calculation methods are shown in equations (1) and (2).

$$
\begin{gathered}
\text { SFDI }_{i t}=\sum_{s} f d i_{s t} \times \gamma_{i s t} \\
\gamma_{i s}=a_{i s}+\sum_{m=1}^{n} a_{s m} a_{m i}+\sum_{k=1}^{n} \sum_{m=1}^{n} a_{s k} a_{k m} a_{m i}+\cdots
\end{gathered}
$$


In formula (1), $f d i_{\text {st }}$ represents the actual amount of FDI in producer services $s$ in period $t, \gamma_{i s t}$ is the dependence degree of manufacturing industry $i$ on service industry $s$ in $t$ period, which is measured by Leontief's complete consumption coefficient (see equation (2)), and reflects direct consumption and indirect consumption. The greater $\gamma_{i s t}$, the more dependent the manufacturing industry's production activities on service intermediate input. The greater the $f d i_{s t}$, the greater the impact of FDI on the manufacturing industry.

The control variables include: industry size (SCALE), measured by the total output of each industry; industry factor intensity $(K L)$, measured by the ratio of capital return to labour return; labour productivity $(L P)$, measured by average value added per employee; manufacturing FDI level (MFDI), measured by the proportion of total assets of enterprises with foreign investment and investment in Hong Kong, Macao and Taiwan in total assets of all industrial enterprises [9].

\subsection{Model setting}

This paper aims to explore the impact of FDI in producer services on manufacturing carbon emissions. Therefore, the model is constructed with FDI penetration rate of producer services as the core explanatory variable and carbon emission of manufacturing industry as the explained variable. In order to explore the impact of variable changes, logarithm is taken for all variables as shown in formula (3).

$$
\begin{aligned}
\ln C O_{2 i t} & =\beta_{0}+\beta_{1} \ln S F D I_{i t}+\beta_{2} \ln S C A L E_{i t}+\beta_{3} \ln K L_{i t} \\
& +\beta_{4} \ln L P_{i t}+\beta_{5} \ln M F D I_{i t}+\varepsilon_{i t}
\end{aligned}
$$

In equation (3), i represents industry, $\mathrm{t}$ represents time; $\varepsilon_{i t}$ is the error term; $\beta_{0}$ and $\beta_{1-5}$ are constant and the coefficients corresponding to the variables.

\subsection{Data}

This paper selects the panel data of 17 sub sectors of China's manufacturing industry (by matching industry classification standards of different databases) from 2004 to 2014 as samples, and according to relevant policy documents and literature, 5 industries are selected as producer services. The data of carbon emissions are from the results calculated by Cai et al. [9] according to the CEADs database; the data for calculating the complete consumption coefficient are from China's national input-output table of WIOD (2016 Edition); the data of industry scale, value added, employees number and factor intensity are from the SEA of WIOD (2016 Edition); the FDI actual amount of producer services and the data needed to calculate FDI in manufacturing industry are from China Statistical Yearbook (2004-2014).

\section{Results and analysis}

Firstly, the multicollinearity test was carried out, and the results showed that $\mathrm{VIF}<10$, indicating that there was no obvious multicollinearity problem among variables. Secondly, F test, time effect test and Hausman test were conducted, and the results were significant, indicating that there were both individual effects and time effects. Therefore, tow-way FE model should be used for estimation, and the results are shown in Table 1.

Table 1. Model Regression Results.

\begin{tabular}{|c|c|}
\hline Variable & Two-way FE model \\
\hline InSFDI & $\begin{array}{c}-1.247^{*} \\
(0.610)\end{array}$ \\
\hline InSCALE & $\begin{array}{c}1.102^{* * *} \\
(0.306)\end{array}$ \\
\hline lnKL & $\begin{array}{c}0.629^{* *} \\
(0.291)\end{array}$ \\
\hline InLP & $\begin{array}{c}-0.816^{* * *} \\
(0.244)\end{array}$ \\
\hline InMFDI & $\begin{array}{c}0.241 \\
(0.217)\end{array}$ \\
\hline CONs & $\begin{array}{c}-0.110 \\
(6.631)\end{array}$ \\
\hline Industry fixed effects & Yes \\
\hline Year fixed effects & Yes \\
\hline F test & $309.75^{* * *}$ \\
\hline N & 187 \\
\hline
\end{tabular}

Note: (1)*** and $* * *$ are significant at $10 \%, 5 \%$ and $1 \%$, respectively. (2) the values in parentheses are corresponding standard errors.

According to the results in Table 1 , for every $1 \%$ increase in FDI in producer services, the carbon emission of manufacturing industry will decrease by $1.24 \%$, and the result is significant at the level of $10 \%$, which verifies the hypothesis of this paper, that is, FDI in producer services helps to reduce carbon dioxide emissions of manufacturing industry.

In terms of control variables, the impact of industry size and industry factor intensity on carbon emissions is significantly positive, which indicates that the expansion of industry scale and the relative increase of capital factors will promote carbon emissions; the coefficient of labour productivity change is negative, which indicates that improving labour productivity helps to reduce carbon emissions; the coefficient of manufacturing FDI change is not significant, he possible reason is that the increase of FDI in manufacturing industry can both promote and restrain carbon emissions under different circumstances.

\section{Conclusion}

Based on the panel data of China's industries from 2004 to 2014, this paper theoretically analysis the impact of FDI in producer services on industrial carbon emissions, and then verifies it through the two-way FE model. It is 
found that FDI in producer services can reduce industrial carbon emissions by optimizing the input structure of manufacturing industry, improving productivity and technical level, as well as the management level and resource allocation ability of manufacturing enterprises. To sum up, it is necessary to develop producer services continuously, actively guide multinational companies to invest in China's producer services, and promote the development of local producer services through benign competition and technology spill-over, to promote economic development and reduce industrial carbon emissions.

\section{References}

1. F.Han, R. Xie. Does the Aggelomeration of Producer Services Reduce Carbon Emissions ?[J]. Research on quantity economy, technology and economy,34,3 :40-58(2017).

2. Z. Jia, X. Yang. The Relationship between FDI and Reginal $\mathrm{CO}_{2}$ Emission: Dynamic Threshold Effect Based on Intellectual Property Protection[J]. Technical Economy,39,9:101-109(2020).

3. Y. Liao. Research on the Impact of FDI on China's Carbon Emissions at the Level of Human Capital[J]. Journal of Mudanjiang University, 29, 9: 20-24 (2020).

4. C. Ji, L. Jiang. FDI in Service Industry, Upgrade of Industrial Structure and $\mathrm{CO}_{2}$ Emission in China[J].
Journal of Guangxi University of Finance and Economics,26,5 :42-49(2013).

5. Y. Huang, J. Xie. Input Servitization of Manufacturing Industry and Carbon Emission Intensity -Empirical Analysis Based on WIOD's Cross-country Panel[J]. Finance \& Trade Economics, 40,8:100-115(2019).

6. X. Hu, Y. Yao, M. Chen. Environmental Pollution Impacts under the Interaction of Technological Innovation Output and Producer Service Industry Concentration: Empirical Evidence of China from the Dynamic Perspective[J]. Ecological Economy, 36,1:56-62(2020).

7. L. Cai, Z. Zhang, L. Zhu. Global Value Chain Embeddedness and Carbon Dioxide Emissions - An Empirical Study Based on Panel Data of China's Industries[J]. International Trade Journal, 4:86-104(2020).

8. J. Arnold, B. Javorcik, A. Mattoo. The Productivity Effects of Services Liberalization: Evidence from the Czech Republic[J]. Journal of International Economics,85,1: 136-146(2011) .

9. J. Qi, H. Xu. Industry Heterogeneity, Appropriate Intellectual Property Protection and Technology Progress of Export__ Analysis Based on the Panel Data of Chinese Industries [J]. China Industrial Economics, 2:79-88(2012). 